\title{
Research on the Investment and Financing Mode of China's "Go Global" Railway Strategy
}

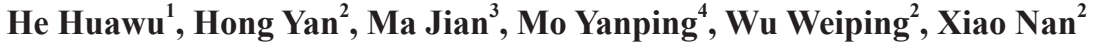 \\ 1. China Railway, Beijing 100844, China \\ 2. China Railway Economic and Planning Research Institute, Beijing 100038, China \\ 3. China Development Bank, Beijing 100036, China \\ 4. The Export-Import Bank of China, Beijing 100031, China
}

\begin{abstract}
This paper analyzes the current situation and problems of investment and financing in China's "Go Global" railway project, and summarizes the investment and financing mode of Japanese overseas railway projects. By analyzing the investment and financing modes of different types of China's "Go Global" railway projects and markets, this paper points out that the government should provide policy and financial support for the construction of railway projects in underdeveloped countries with certain geopolitical characteristics and the "Belt and Road" or connectivity background, as well as those that further strategic objectives relating to national security. This paper also offers suggestions to reduce financing costs through financial or policy support by the government and proposes some policy suggestions, such as strengthening cooperation among enterprises, establishing an international railway strategy cooperation committee, and identifying the national strategic project in advance.
\end{abstract}

Keywords: China's "Go Global” railway strategy; investment and financing; financing cost; national strategic project; investment and financing mode

\section{Status quo of investment and financing for China's "Go Global" railway strategies}

During China's "Go Global” railway process, aided by the significant support and active promotion of the Chinese Government, and further relying on their core technological advantages, railway enterprises have continuously expanded their existence in overseas markets. Important progress has been made in the practical railway cooperation seen in the China-Laos, China-Indonesia, China-Russia, and China-Thailand bilateral deals; major breakthroughs have been made during the "Go Global" process, which has seen locomotives, passenger cars, freight cars, electric multiple units (EMUs), metro vehicles, and tramcars made in China enter the European and American markets. Although the current financial support is strong, the investment and financing mode of China's "Go Global" railway is still at the early stage, there is no safeguard mechanism, and the engagement of departments and enterprises related to the whole industry chain is insufficient. For example, most of the China's "Go Global" railway projects adopt the "financing + engineering, procurement, and construction $(\mathrm{F}+\mathrm{EPC})$ " mode for project execution. In this mode, the general contracting right is obtained on the premise that China will provide the host country with project loans. Breakthrough has been made in the Jakarta-Bandung High-Speed Railway Project in Indonesia, where the "public-private partnership (PPP)" mode has been adopted. The main financing channels of China's "Go Global" railway projects include own funds of railway enterprises and bank loans (including syndicated loans); there is very little equity investment.

Received date: September 15, 2017; Revised date: October 15, 2017

Corresponding author: He Huawu, Chinese Academy of Engineering, Academician. Major research field is railway construction engineering. E-mail: hehuawu@ china-railway.com.cn

Funding program: CAE Advisory Project “Research on China's ‘Go Global' Railway Strategy” (2015-ZD-11)

Chinese version: Strategic Study of CAE 2017, 19 (5): 027-032

Cited item: He Huawu et al. Research on the Investment and Financing Mode of China's “Go Global” Railway Strategy. Strategic Study of CAE, https://doi. org/10.15302/J-SSCAE-2017.05.005 


\section{Ways of Chinese financial institutions supporting China's "Go Global" railway strategies and problems therein}

\subsection{Ways of Chinese financial institutions supporting China's "Go Global" railway strategies}

As the policy-based financial vehicle supporting the openingup and promotion of an open economy in China, the ExportImport Bank of China helps Chinese railway enterprises strengthen their international competitiveness in various ways. These include two kinds of concessional loans (government concessional loan and preferential buyer's credit), export seller's credit, export buyer's credit, and mutually beneficial cooperation loans. China's "Go Global" railway projects supported by the Export-Import Bank of China include the following: Addis AbabaDjibouti Railway; Mombasa-Nairobi Railway and NairobiMaraba Railway in Kenya; Hungary-Serbia Railway; and the Benguela Railway in Angola.

As a development financial institution and the main bank for foreign investment and financing, China Development Bank provides substantial support for national financing along the "Belt and Road" and is involved in multiple transport infrastructure projects. China's "Go Global" railway projects supported by the China Development Bank include: Jakarta-Bandung High Speed Railway; Boten-Vientiane Railway; Moscow-Kazan High-speed Railway; and Phase II of the Ankara-Istanbul High Speed Railway.

China Export \& Credit Insurance Corporation provides enterprises with strong support in treating overseas investment and financing risks, as well as financing insurance support for the export of railways, locomotives, and passenger cars. China's "Go Global" railway projects supported by China Export \& Credit Insurance Corporation include the: Addis Ababa-Djibouti Railway; Mombasa-Nairobi Railway; and the Belgrano Cargas Railway Reconstruction Project [1].

\subsection{Major problems}

China's "Go Global" railway efforts require efficient and low-cost financial services provided by financial institutions. However, financial institutions face the following problems.

First, high risks and the fact that risks in the railway markets of different countries vary greatly. Developed countries in Europe and America have investment demand for equipment replacement, renovation, and speed-up. These countries have great financial strength and the investment projects have certain economic benefits; however, it is very difficult for foreigners to get involved or participate in these projects since the barriers to entry are very high. The railway markets in developing countries are characterized by high demand. However, the country risks are also high; further, financing gaps are prevalent, and the economic benefits are uncertain.
Second, there is fierce competition in the international railway market, and China is at a disadvantage when it comes to financial support. At present, the international railway market has railway industry powerhouses, such as Japan, France, Germany, and Spain, and the competition among them is fierce. Japan is the main competitor of China railway in its "Go Global" efforts. In the competition for executing the first Indian high-speed railway, the "Mumbai-Ahmedabad" project, Japan won the project by providing a USD 12 billion loan at an ultra-low interest rate $(0.1 \%)$ and ultra-long repayment period (50 years) [1]. Japan has implemented the low interest rate policy for a long time, while the interest rate in China is high and the cost of bank funds is correspondingly high. Since the financial conditions are different, the financial institutions in China cannot match the low loan rate provided by Japan.

Third, a fundamental conflict exists between a strategic project and market-oriented operations. Most of China's "Go Global" railway projects are strategic projects that face problems, such as long period of investment and financing, large capital demand, and a high yield risk. Since the financial institutions are subject to market-based operations, taking investment benefits and risks into consideration, a conflict exists between the strategic projects and the market-based, economic-benefit-seeking operation of financial institutions. What China railway really needs for going global is policy support and risk compensation from national financial institutions.

\section{Investment and financing mode of Japan's "Go Global" railway strategies}

\subsection{Japanese investment and financing practices in its overseas railway projects}

The Japanese government has continuously increased the policy support for railway enterprises" "Go Global" efforts. The core policy of the Japanese government is to explore the international market and market Japan's superior railway technologies through cooperation between the government and enterprises. The concrete measures include (1) strengthening the mechanism of marketing by senior government officials; (2) promoting its railway standards in the international market; (3) improving the financial support mechanism and increasing the support in respect of infrastructure funds, official development assistance funds (ODA funds), credit guarantee, trade insurance, and taxation system; (4) promoting the Public-Private Partnership/Private Finance Initiative (PPP/PFI) construction mode, improving the systems for infrastructure investment and financing, absorbing private capital, and establishing an overseas infrastructure construction scheme based on the PPP mode [2]. With the support from the government, the benefits of the enterprises participating in Japan's "Go Global” railway efforts are guaranteed through multiple investment and financing modes. 
With its systems and mechanisms as the guarantee, the Japanese government established the National Strategic Project Committee. The Prime Minister and the Minister for National Strategy serve as the chairman and the acting chairman, respectively, of the committee. The committee guides and coordinates relevant enterprises to develop the cooperation between the government and enterprises and deal with overseas railway infrastructure EPC projects. As for the operation, the National Strategic Project Committee will determine the capital operation mechanism. On October 20, 2014, Japan established the Japan Overseas Infrastructure Investment Corporation for Transport \& Urban Development (JOIN) [2]; it provides support to enterprises in various areas, such as investment, dispatching management and technical personnel, and conducting negotiations with local governments on relevant issues. JOIN selects the projects to be supported on the basis on four standards; see Table 1 for specifics. It further encourages Japanese enterprises to expand their overseas businesses by providing assistance. At the same time, Overseas Project PPP Promotion was established by government departments including the Ministry of Land, Infrastructure, Transport and Tourism; the Ministry of Foreign Affairs; the Ministry of Economy, Trade and Industry; Japan Bank for International Cooperation; Nippon Export and Investment Insurance; and 52 Japanese enterprises. These would be responsible for resolving the major issues, as determined by the minutes of the bilateral talks between governments, and providing all-round support for Japan's "Go Global” railway efforts.

\subsection{What it tells us}

It is difficult to select the right investment and financing mode for China's "Go Global" railway efforts, as railway projects call for large investment but the returns may be low. Further, all the relevant problems cannot be solved only through market tools; thus, government support is needed.

China's "Go Global" railway is in urgent need of different types of government support, such as capital, credit guarantees, insurance, and tax relief.

The cooperation between the government and enterprises is needed to complete the investment and financing mode, so as to cope with the investment and financing mechanism of overseas railway projects. In addition, the participation of the relevant government organizations and private enterprises in the entire industry chain is required.

\section{Investment and financing mode of China's "Go Global" railway strategy}

\subsection{Principles to be followed in investment and financing of China's "Go Global" railway strategies}

It shall be driven by the government and be enterprise-oriented. The government shall strengthen overall coordination, improve supportive polices, and create favorable environment and conditions. The enterprises shall follow the law of the market and the commonly accepted international rules, as well as select and operate specific projects according to the market demand and their actual abilities.

Different policies shall be implemented for different specialties, and measures shall be taken based on actual circumstances. Since there is large difference in market demand and environment in areas such as railway survey and design, building construction, technical equipment, and operations management, targeted policies must be implemented for different specialties. Key areas shall be highlighted and specific circumstances of different areas and different markets shall be understood, so as to allocate limited resources to the most crucial areas and projects.

Steady steps shall be taken to prevent and control risks.

Table 1. Standards of JOIN for selecting projects to be supported.

\begin{tabular}{|c|c|}
\hline Factors of selection & Standard \\
\hline \multirow[t]{4}{*}{ Policy implication } & (1) Capable of promoting the enterprises in the overseas market \\
\hline & (2) Effective organization support \\
\hline & (3) In line with the foreign policies of Japan \\
\hline & (4) Based on environmental and social considerations \\
\hline \multirow[t]{4}{*}{ Initiative of the enterprise } & (1) The enterprise is willing to expand overseas business \\
\hline & (2) It is expected that the funds will be provided by private companies, among others \\
\hline & (3) Cooperate with private enterprises; JOIN participates in relevant business \\
\hline & (4) JOIN will not become the largest equity investor of Japanese business operators \\
\hline \multirow[t]{3}{*}{ Long-term returns } & (1) Capable of performing reasonable operational tasks \\
\hline & (2) With long-term returns \\
\hline & (3) With high possibility of funds recovery upon the completion of the project \\
\hline Relationship with other public institutions & In partnership with other public institutions, with sufficient level of cooperation \\
\hline
\end{tabular}


The analysis and evaluation on the host country in respect of politics, economy, laws, and the market shall be carried out earnestly to strengthen the feasibility study and verification of the projects; reasonable planning shall be made actively to push forward the progress of the project actively, orderly, and effectively; risks shall be recognized as early as possible, and measures taken to prevent and control them; risk evaluation and prevention and controlling mechanism shall be established and improved.

\subsection{Investment and financing modes for different industries}

\subsubsection{Design consulting industry}

Generally, the design consulting industry's "Go Global" efforts refer to the dispatching of expert groups to the host country to carry out the preliminary study for the project. This is crucial for seizing market opportunities.

Chinese design consulting enterprises can "go global" by using capital. They can "go global" through merger with, or acquiring a share in famous overseas design consulting companies; this would not only help them in learning from each other, in talent training, and in following best international practices, but also in the overall improvement of their influence and competitiveness.

\subsubsection{Building construction industry}

The building construction industry can "Go Global" through the combination of various financing and investment modes. For example, PPP mode can be adopted for an overseas railway project; a project company can be established by the relevant Chinese enterprises in partnership with the government and enterprises of the host country; the cooperation in investment would help in sharing the risks. The project company shall be responsible for project financing through various means, such as debt financing. During the construction stage, the project company can adopt the EPC mode for the construction of fixed facilities; during the operation stage, the demand for mobile devices can be satisfied through financial leasing.

Generally speaking, the PPP mode is more relevant to the "Go Global" efforts of the whole railway industry chain at present. However, traditional modes such as "F+EPC" will still be the common modes for "Go Global" railway construction strategy.

\subsubsection{Equipment manufacturing industry}

The market opportunities for the equipment manufacturing industry's "Go Global" efforts are tremendous. The industry can "Go Global" by adopting different modes during different development stages.

During the product exporting stage, the buyer's and seller's credit shall be the focus. During the stage of promoting both product exports and technical capital exports, the merging and reorganization of the enterprises will have to be highly professional and case-specific; further, financing support and reasonable application of funds are required. During the service exporting stage, the trend of turning from exporter into service provider can be followed, and the demand for leasing business is large.

For improving the convenience of international settlement, possible exchange rate risks, credit risks, and default risks shall be reduced and mitigated; support from financial institutions is required for improving enterprise capital liquidity.

\subsection{Investment and financing modes for different markets}

\subsubsection{Strategic projects in developing countries}

For railway projects with obvious geopolitical characteristics, that is, those in countries along the "Belt and Road," those that may improve the interconnections among countries, or those involving strategic objectives concerning national security, national support shall be offered and they will receive higher priority when national subsidies are available. For example, the ChinaLaos Railway, the China-Pakistan Railway, and railway projects in Africa are related to the overall national strategy but their profitability is poor. Since most host countries lack financial strength, the construction of these projects will mainly depend on the preferential financial support provided by China. For these projects, besides financing support channels, such as the "two kinds of concessional loans," special policy support shall also be given through other government channels [1].

\subsubsection{Railway projects in developed countries}

It is very difficult to participate in the construction of railway projects in developed countries and the decision-making process of these projects is complicated and subject to frequent changes. For these projects, market-oriented operation mode shall be the first choice; efforts shall be made to improve the management level, product competitiveness, operating capacity, and the quality of the human resources of the railway enterprises to meet the requirements of the host countries' market.

The investment and financing mode shall be selected from the perspective of maximizing the benefits; a combination of different financing tools shall be used; and the operation shall be carried out in a market-oriented way.

\subsubsection{Railway projects related to resource export}

The financing of railway infrastructure construction projects is related to the economic development and resource exploitation situation in the host country.

For countries and regions along the "Belt and Road," there is great potential for trading resources and energy for projects. The cooperative construction with resource enterprises mode can be 
adopted: the railway enterprise can be responsible for railway construction, and the resource enterprise can be responsible for resource exploitation; both parties can make investments according to an agreement and raise funds by mortgaging project assets. Other modes, such as obtaining loans provided by China and obtaining the mining rights, petroleum, or agricultural products of the host countries as the repayment guarantee can also be adopted.

4.3.4 Railway projects related to the export of Chinese railway technologies

The construction of railway projects related to the export of Chinese railway technologies can effectively promote the technical standards of China's railway and be helpful in establishing the international marketing network of railway products. Therefore, the future benefits of railway product export shall be incorporated into the scope of project evaluation, and the return on investment shall be considered from the perspective of improving the international competitiveness of China's railway; railway product marketing funds shall be established to partially solve the project cost problems. The mode of "government investment + bank loan + other financing methods" shall be adopted.

\subsection{Select a combination of various investment and financing} modes for specific projects

For China's "Go Global" railway projects, overall and systematic consideration of specific national situations shall be made to propose comprehensive and systematic solutions during the process of "bridging" by the governments and the practical implementation by enterprises. The investment and financing mode must be on the basis of multiple factors, including project situation, benefit evaluation, as well as bilateral and multilateral relationships. Both technical and commercial factors shall be taken into consideration; all modes shall be applied comprehensively, and a combination of various investment and financing modes is required.

\section{Solutions and suggestions}

\subsection{Solutions and suggestions for financial institutions to support China's “Go Global” railway strategies}

Since the competition in the international railway market is fierce, helping the host country raise railway construction funds and strengthening financial support have become important ways of improving China's railway competitiveness.

5.1.1 Get involved in the preliminary work of the project and provide all-round financial service for railway construction

The financial institutions shall get involved in the groundwork of the overseas railway projects, help the enterprises carry out project risk analysis and financing plan design, and participate in the preliminary feasibility study; all these will enable substantial progress of the project at a fast pace.

The financial institutions shall also carry out in-depth research on the financial requirements of enterprises at different stages, depending on the market conditions of the host countries, and provide enterprises with a package of comprehensive financial services and all-round financial support covering financing, consulting, settlement, insurance, and risk management.

\subsubsection{Financial institutions' call for national policy support}

Financial institutions need national policy support in lowcost financing, interest subsidy, tax preference, and differential assessment. For example, in order to reduce financing cost, the United States government bonds held by China can be used as the guarantee for the overseas issuance of targeted US dollar bonds by financial institutions; the financial institutions can be allowed to issue domestic bonds carrying an interest rate not higher than that of overseas foreign currency bonds; the business of international financial leasing of railway equipment can be supported; the financial institutions can be supported to develop innovative financial instruments and intermediate business based on the requirements of international railway cooperation; the central government can allocate special funds for loans with discounted interest rates and premium subsidies for strategic railway projects; differential assessment policy can be implemented for financial institutions and railway enterprises according to the actual project conditions.

\subsubsection{China's foreign exchange reserves shall be fully utilized}

We should promote the diversified use of foreign exchange reserves. Low-cost foreign exchange fund sources of financial institutions can be increased and the foreign cost can be reduced in many ways, such as using foreign exchange reserves to entrust loans and targeted bond issuance, so as to reduce the loan interest rate level of the enterprises and increase the market competitiveness of China railway in going global.

5.1.4 Support strategic railway projects and reduce enterprise insurance expenses

Insurance companies, represented by China Export \& Credit Insurance Corporation, shall be encouraged to design customized insurance business according to the characteristics of the overseas railway projects, to provide better support for China's "Go Global" railway strategy. The support for high-end equipment export projects, international production capacity layout investment projects, and large contracting projects with own capital shall be strengthened; the coverage of overseas investment insurance shall be expanded; sufficient coverage shall be ensured for risk-controllable projects. Overseas railway investment insurance system shall be established and improved; the government can bear insurance premium for strategic railway projects based 
on the actual conditions, or provide premium subsidy for insured enterprises to reduce their insurance expenses.

\subsection{Relevant policy advices}

\subsubsection{Strengthen the cooperation among enterprises}

By strengthening the cooperation and coordination among enterprises, the following goals are expected to be attained. First, adapting to the transformation of international railway project cooperation mode to such modes as PPP and "packaged" implementation of the whole industry chain; promoting the cooperation between domestic railway construction and operation enterprises and financial enterprises or enterprises of other relevant fields; and improving the overall competitiveness of the enterprises in the international railway market. Second, strengthening the self-regulation of the enterprises in the international railway market and preventing disordered and cutthroat competition among enterprises. Third, promoting integration of resources; achieving resource (platform, information, etc.) sharing; and concentrating on cooperation and coordination.

Chinese enterprises' collaborative "Go Global" mode is an important premise and foundation for the investment and financing modes of "Go Global"; both the collective interest and the individual interest of relevant enterprises shall be taken into consideration, and the cooperation mode shall be properly designed to ensure all of their efforts are well aligned.

\subsubsection{Establish international railway cooperation strategy committee}

An international railway cooperation strategy committee shall be established and managed by a standing body; its implementation powers shall be increased to organize and coordinate relevant enterprises better. The cooperation between the government and enterprises shall be developed to cope with major overseas railway projects. An institutionalized, organizational platform among enterprises shall be established by integrating resources of the National Development and Reform Commission of People's Republic of China, the Ministry of Commerce of the People's Republic of China, industry associations, and China Council for the Promotion of International Trade; an international railway cooperation strategy alliance for enterprises shall be established by the enterprises involved in railway design and construction, equipment manufacturing, and operation management, in partnership with the financial institutions such as the Export-Import Bank of China, China Development Bank, China Export \& Credit Insurance Corporation, and China Investment Corporation [1].

5.2.3 National strategic projects of China's "Go Global” railway shall be identified in advance

National strategic projects refer to national-interest-oriented overseas railway construction projects serving the demands of national politics, economy, and national defense (generally refers to the projects covered by the cooperation agreements signed under the intergovernmental cooperation mechanism). Characteristics of these projects are that they serve the strategic policies on national diplomacy and foreign economic relations and trade; they are not profit-oriented; and the funds provided by Chinese agency are available through non-reimbursable assistance, interest-free loans, and concessional loans. The implementation of strategic "Go Global" projects can show the world the superior level of the China's railway construction expertise and the advantages of safe and high-quality locomotive equipment; enhance the position of China in global economy; comply with the initiative of the "Belt and Road;" and improve the relationship with relevant nations and regions. Strategic projects are not profit-oriented; national interest is paramount in these projects and it is difficult for enterprises to bear relevant investment risks on their own. Therefore, the government shall be responsible for a certain proportion of the investment and the projects shall be identified in advance.

\subsubsection{Establish an international railway cooperation fund}

An international railway cooperation fund shall be established, mainly for implementing national strategies, making investment in strategic international cooperation projects, and obtaining reasonable return from these projects. Support funds for the railway industry's "Go Global" efforts shall be established to make direct investment in the construction of inter-governmental railway cooperation projects, support the preliminary work carried out by the enterprises for overseas railway projects through full funding or appropriate subsidy, and provide targeted preferential financing policies.

5.2.5 Inter-governmental regional international financial institutions shall be given full play

Regional international intergovernmental financial institutions, such as Asian Infrastructure Investment Bank (AIIB), New Development Bank (NDB), SCO Interbank Consortium, and China-ASEAN Interbank Consortium, which have been established or are going to be established because of the initiative taken by China, shall be given full play to provide development financial support for railway international cooperation. Silk Road Fund, China-Africa Development Fund, China-Africa Fund for Industrial Cooperation, China-ASEAN Investment Corporation Fund, China-Latin Energy Cooperate Investment Fund, and CIC Capital Corporation shall be given full play [3] to actively support the China's "Go Global" railway through various investment modes, such as stock rights and bonds.

\section{References}

[1] Xiao N, Wu W P. Research on the strategy of China high-speed 
railway export supported by financial institutions [J]. Railway Economics Research, 2017(4): 18-21. Chinese.

[2] Zhang J C. Study on the mechanism of Japan attending foreign railway construction projects [J]. Railway Transport and Economy,
2015, 37(10): 67-73. Chinese.

[3] Luo Y Z. Study on financing and investment mechanisms for infrastructure connectivity of the Belt and Road Initiatives [M]. Beijing: China Development Press, 2015. Chinese. 